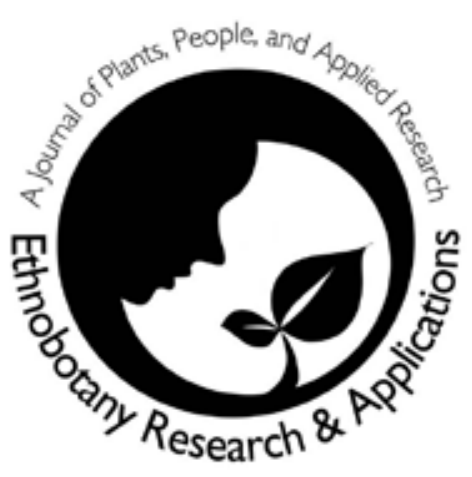

\title{
Ex-situ Management Study of Some High Value Medicinal Plant Species in Swat, Pakistan
}

\author{
Hassan Sher, Farrukh Hussain and Hazrat Sher
}

\section{Research}

\begin{abstract}
An ex-situ experiment was conducted to evaluate the growth performance of six medicinal species (Aconitum laeve Royle, Bunium persicum B. Fedtsch., Saussurea costus (Falc.) Lipsch., Podophyllum hexandrum Royle, Delphinium roylei Munz and Hypericum perforatum L.) from upper Swat, Pakistan. Experiments were conducted at four different locations in the upper Swat valley at altitudes ranging from 1200 to 1900 m.a.s.l. The objectives were; 1) to determine the suitability of ex-situ cultivation of different medicinal species, and; 2) to assess the economic feasibility of growing medicinal plants in the area. A highest mean survival of $80.7 \%$ across all locations was observed for $H$. perforatum followed by $58.7 \%$ for $B$. persicum. The remaining four species exhibited very poor survival rates, although $D$. roylei, did show encouraging signs of growth and flowered, before experiencing high mortality rates late in the trial. Altitude generally seemed to enhance the degree of sprouting for all species except $H$. perforatum. However, the productive yield of $H$. perforatum was certainly not reduced, but rather slightly enhanced in the higher altitude sites. Overall, cultivation of only two of the investigated species, $B$. persicum and $H$. perforatum, appeared successful and potentially economically viable under farmland conditions at upper Swat.
\end{abstract}

\section{Introduction}

A medicinal plant is one that contains chemical substances in one or more of its parts (roots, leaves, stems, flowers, fruits or seeds), which can be used for therapeutic purposes or serve as starting material for chemical pharmaceutical synthesis (Khan 1991). Therefore, the potential economic values of such plants are obvious. Lange (1998) reported that some medicinal and aromatic plants like Lavendula spp., Carum carvi L., Foeniculum vulgare Mill., Thymus vulgaris L. and Althaea rosea (L.) Cav. are cultivated over an estimated area of 70,000 ha in the Eu- ropean Union, playing a significant role in its economy. Similarly, in the Peruvian Amazon, medicinal plants are an important industry, with about 100 species currently in cultivation, which are processed into powders, ointments and other plant extracts (Lange 1998). Given the increasing market and the threat of over-collection, these authors suggested that cultivation of medicinal plant species is the only solution for their rapid conservation.

Several workers have noted the need to conserve threatened species of medicinal plants in sub-continental Asia. Hussain and Sher (1998) observed that substantial extraction of medicinal plants has resulted in the depletion of existing populations of many valuable species. At present some of these valuable species can only be found growing in small scattered populations in remote areas. Khan (1989) reported that medicinal species such as Dioscorea deltoidea Wall. ex Griseb., Saussurea costus (Falc.) Lipsch. (syn. S. lappa (Decne.) Sch. Bip.) and Colchicum luteum Baker are rapidly becoming endangered. As a response to the looming threat of over-collection and extinction, several workers have investigated the possibility of cultivating useful plants. Zaidi (1998) studied

\section{Correspondence}

Hassan Sher, Department of Botany, Islamia College University Peshawar, PAKISTAN.

hassan.botany@gmail.com;hassansher_2000@yahoo.com

Farrukh Hussain, Department of Botany, University of Peshawar, PAKISTAN.

Hazrat Sher, Kuhat University of Science and Technology, Kuhat, PAKISTAN.

Ethnobotany Research \& Applications 8:017-024 (2010)

Published: February 15, 2010 
the ex-situ cultivation of 14 condiments and spices in various parts of Punjab and in plains of North-West Frontier Province (NWFP). He also worked on the cultivation of Althaea rosea (L.) Cav. in Peshawar valley. Along similar lines, Goel et al. (1997) studied the ex-situ conservation of Encephalartos species in the botanical garden at Lakhnawo, India. They evaluated their economic value, horticultural importance, propagation, cultivation, ecology and conservation needs.

The fate of many medicinal plant species is typified by the findings of Joshi and Rawat (1999) who reported that medicinal and aromatic plants of alpine and sub-alpine areas of the North-West Himalayas have been rapidly depleted and are endangered due to deforestation, over-grazing, habitat loss and over-exploitation. They recommended an urgent need for conservation of threatened medicinal plant species in various parts of Swat and suggested insitu and ex-situ cultivation of these plants as a conservation strategy for such species.

Traditionally forests and rangelands are the main sources of medicinal plants in Pakistan. In this study we examined six species: Aconitum laeve Royle, Bunium persicum B. Fedtsch., Saussurea costus (Falc.) Lipsch., Podophyllum hexandrum Royle, Delphinium roylei Munz and $\mathrm{Hy}$ pericum perforatum $\mathrm{L}$. These plants all occur naturally in the Swat district, are used as a basis for modern pharmaceuticals, and therefore are commonly exploited commercially. Since these plants usually occur in wild form and have been collected from the forest for decades (Khan 1989), their cultivation has been neglected in the past; hence no nurseries or protected areas for these plants exist in Swat.

Only very limited information is presently available regarding the cultivation of medicinal plant species in the Swat district. The present study was, therefore, initiated with the objectives; 1) to evaluate the cultivation prospects of the aforementioned important medicinal plant species and 2) to assess the economic feasibility of commercially cultivating such medicinal plant species under typical farming conditions.

\section{Materials and Methods}

\section{Site and plant selection}

The ex-situ cultivation of the six medicinal plant species was undertaken in four different locations on farmers' fields in high altitudes of the Swat valley during 20002001. These locations included the villages of Mingora, Dasu, Kandia and Kalam at altitudes of 1200, 1400, 1600 and 1900 meters above sea level (m.a.s.I), respectively (Figure 1). The criteria for selection of species were: 1) they have high commercial value and have been overexploited in the area, 2) they are becoming rare due to indiscriminate destruction of their natural habitat because of urbanization, and 3) the local people were interested in their cultivation. The criteria for selection of sites were: 1) local people in these locations were interested in cultivation of medicinal plants, 2) a nearby in-situ study area existed which could be used for comparison, and 3) these locations had good forest plantation management and had altitude variations ranging from 1200 to 1900 m.a.s.I. .

\section{Plant cultivation}

In September, 2000, rhizomes of $P$. hexandrum, A. laeve, $D$. roylei, $B$. persicum and $S$. costus were collected from the Shinko alpine pasture of Madyan area, and $H$. perforatum rhizomes were collected from their natural habitat at Kalam village. The rhizomes were cut into small pieces ( 4 to $6 \mathrm{~cm}$ in size), each with 2 to 3 active buds. Rhizomes were planted in experimental plots the day after they had been collected.

The soil of each location was analyzed in the Soil Testing Laboratory of the Agricultural Research Station, North Mingora, Swat (Table 1).

The experiment was conducted as randomized complete block design (RCBD) using each location as replication. The plot size for each species consisted of $3 \times 3$ meters at each location. Planting was done during mid-September, 2000 on a well-prepared soil using farm yard manure to improve soil fertility. For $B$. persicum and $H$. perforatum, a plant to plant distance of $4 \mathrm{~cm}$ and a row to row distance of $8 \mathrm{~cm}$ was used. The remaining four species were

Table 1. Physical and chemical properties of soils of four experimental locations in Swat District, Pakistan during 20002001.

\begin{tabular}{|c|c|c|c|c|c|c|c|c|c|c|}
\hline \multirow[t]{2}{*}{ Site } & \multirow[t]{2}{*}{ Location } & \multirow{2}{*}{$\begin{array}{l}\text { Altitude } \\
\text { (m.a.s.I.) }\end{array}$} & \multirow{2}{*}{$\begin{array}{l}\mathrm{CaCO}_{3} \\
(\%)\end{array}$} & \multirow{2}{*}{$\begin{array}{l}\text { Organic } \\
\text { Matter } \\
(\%)\end{array}$} & \multirow[t]{2}{*}{$\mathrm{pH}$} & \multirow{2}{*}{$\begin{array}{l}\text { Textural } \\
\text { Class }\end{array}$} & \multirow{2}{*}{$\begin{array}{l}\text { Water } \\
\text { Holding } \\
\text { Capacity } \\
(\%)\end{array}$} & \multicolumn{3}{|c|}{ Soil Primary Nutrients (\%) } \\
\hline & & & & & & & & $\mathbf{N}$ & $\mathbf{P}$ & $\mathbf{K}$ \\
\hline 1 & Mingora & 1200 & 0.27 & 3.61 & 7.3 & Silt loam & 23.11 & 5.7 & 4.2 & 5.3 \\
\hline 2 & Dasu & 1400 & 0.49 & 4.91 & 7.0 & Silt loam & 22.24 & 6.9 & 6.9 & 7.0 \\
\hline 3 & Kandia & 1600 & 0.86 & 2.31 & 7.5 & Sandy loam & 21.20 & 3.6 & 3.7 & 4.4 \\
\hline 4 & Kalam & 1900 & 0.36 & 4.62 & 7.4 & Silt loam & 19.11 & 6.2 & 7.1 & 7.7 \\
\hline
\end{tabular}




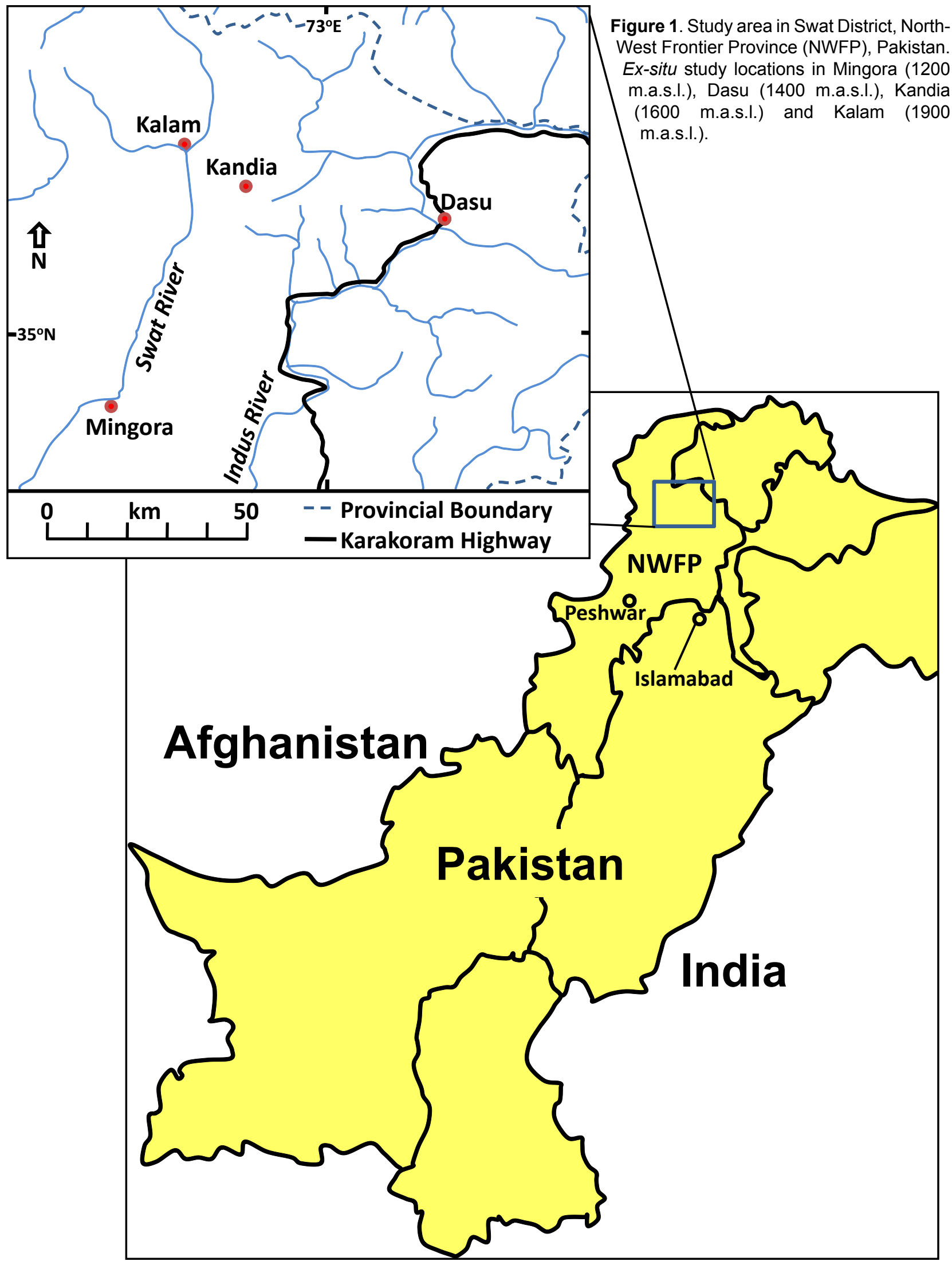


Table 2. Days to sprouting for six medicinal species evaluated in four different locations under farmland conditions in Swat District, Pakistan during 2000-2001. Values with the same letter superscripts are not significantly different $(\mathrm{P}<0.05)$.

\begin{tabular}{|c|c|c|c|c|c|}
\hline \multirow[t]{2}{*}{ Species } & \multicolumn{4}{|c|}{ Locations } & \multirow{2}{*}{$\begin{array}{c}\text { Location } \\
\text { Means } \\
\text { (days) }\end{array}$} \\
\hline & $\begin{array}{c}\text { Mingora } \\
1200 \\
\text { (m.a.s.l.) }\end{array}$ & $\begin{array}{c}\text { Dasu } \\
1400 \\
\text { (m.a.s.I.) }\end{array}$ & $\begin{array}{c}\text { Kandia } \\
1600 \\
\text { (m.a.s.I.) }\end{array}$ & $\begin{array}{c}\text { Kalam } \\
1900 \\
\text { (m.a.s.I.) }\end{array}$ & \\
\hline Aconitum laeve Royle & 160 days & 160 days & 170 days & 165 days & $164^{\mathrm{b}}$ \\
\hline Bunium persicum B. Fedtsch. & 35 days & 35 days & 25 days & 20 days & $31^{c}$ \\
\hline Delphinium roylei Munz & 165 days & 175 days & 175 days & 175 days & $173^{\mathrm{ab}}$ \\
\hline Hypericum perforatum L. & 170 days & 175 days & 175 days & 190 days & $178^{\mathrm{a}}$ \\
\hline Podophyllum hexandrum Royle & 160 days & 165 days & 165 days & 175 days & $166^{\mathrm{ab}}$ \\
\hline Saussurea costus (Falc.) Lipsch. & 170 days & 170 days & 150 days & 190 days & $170^{\mathrm{ab}}$ \\
\hline
\end{tabular}

Comparison of means using Least Significant Difference test at $5 \%$ probability level > $\quad 11.58$

planted with distance of $30 \mathrm{~cm}$ between rows and $15 \mathrm{~cm}$ between plants.

Weeds were controlled by hand weeding and hoeing in each location during December, 2000 and during April and May, 2001. Data were recorded for various parameters on each plot which included number of days to achieve $50 \%$ sprouting, sprouting percentage, survival percentage, number of days from sprouting to flowering, plant height and yield of usable plant parts (rhizomes, shoots, leaves and flowers). Harvesting of $B$. persicum and $H$. perforatum was done during the months of April and May, 2001 while rhizomatous species, i.e., $P$. hexandrum, $A$. laeve, $D$. roylei and $S$. costus were harvested in September and October, 2001.

Data were analyzed using analysis of variance procedures for randomized complete block design, considering locations as replications, using MSTAT-C. Means were compared using Least Significant Difference (LSD) test at $5 \%$ probability level (Steel \& Torrie 1980).
Economic analyses of yield data were carried out to determine the net income for each medicinal plant species, using prevailing market rates for land rent, costs of production and prices of usable plant parts relevant to the species. The most widely cultivated crops, wheat and maize among cereals and tobacco among cash crops, were included for comparison.

\section{Results}

Data regarding growth, flowering and yield parameters for six medicinal species under farm land conditions in four different locations and their means across locations is presented in Tables 2 through 7. Productive yield data (i.e. rhizome, flower or leaf/shoot), for the six medicinal species in the four test locations is given in Table 7. Economic analysis of the results is reported in Table 8.

Table 3. Sprouting percentage of six medicinal species evaluated in four different locations under farmland conditions in Swat District, Pakistan during 2000-2001. Values with the same letter superscripts are not significantly different $(P<0.05)$.

\begin{tabular}{|c|c|c|c|c|c|}
\hline \multirow[t]{2}{*}{ Species } & \multicolumn{4}{|c|}{ Locations } & \multirow{2}{*}{$\begin{array}{c}\text { Location } \\
\text { Means } \\
(\%)\end{array}$} \\
\hline & $\begin{array}{c}\text { Mingora } \\
1200 \\
\text { (m.a.s.I.) }\end{array}$ & $\begin{array}{c}\text { Dasu } \\
1400 \\
\text { (m.a.s.I.) }\end{array}$ & $\begin{array}{c}\text { Kandia } \\
1600 \\
\text { (m.a.s.I.) }\end{array}$ & $\begin{array}{c}\text { Kalam } \\
1900 \\
\text { (m.a.s.I.) }\end{array}$ & \\
\hline Aconitum laeve Royle & $4 \%$ & $5 \%$ & $5 \%$ & $20 \%$ & $8.5^{c}$ \\
\hline Bunium persicum B. Fedtsch. & $20 \%$ & $70 \%$ & $90 \%$ & $40 \%$ & $55^{\mathrm{b}}$ \\
\hline Delphinium roylei Munz & $70 \%$ & $80 \%$ & $80 \%$ & $90 \%$ & $80^{a}$ \\
\hline Hypericum perforatum L. & $90 \%$ & $75 \%$ & $75 \%$ & $60 \%$ & $75^{\mathrm{ab}}$ \\
\hline Podophyllum hexandrum Royle & $5 \%$ & $5 \%$ & $5 \%$ & $10 \%$ & $6.2^{c}$ \\
\hline Saussurea costus (Falc.) Lipsch. & - & $3 \%$ & $7 \%$ & $5 \%$ & $4^{c}$ \\
\hline \multicolumn{6}{|c|}{ Comparison of means using Least Significant Difference test at $5 \%$ probability level > } \\
\hline
\end{tabular}




\section{Sher et al. - Ex-situ Management Study of Some High Value Medicinal Plant Species in Swat, Pakistan}

Table 4. Survival percentage of six medicinal species evaluated in four different locations under farmland conditions in Swat District, Pakistan during 2000-2001.

\begin{tabular}{|c|c|c|c|c|c|}
\hline \multirow[t]{2}{*}{ Species } & \multicolumn{4}{|c|}{ Locations } & \multirow{2}{*}{$\begin{array}{l}\text { Location } \\
\text { Means } \\
(\%)\end{array}$} \\
\hline & $\begin{array}{c}\text { Mingora } \\
1200 \\
\text { (m.a.s.I.) }\end{array}$ & $\begin{array}{c}\text { Dasu } \\
1400 \\
\text { (m.a.s.I.) }\end{array}$ & $\begin{array}{c}\text { Kandia } \\
1600 \\
\text { (m.a.s.I.) }\end{array}$ & $\begin{array}{c}\text { Kalam } \\
1900 \\
\text { (m.a.s.I.) }\end{array}$ & \\
\hline Aconitum laeve Royle & $6 \%$ & - & - & - & $2^{c}$ \\
\hline Bunium persicum B. Fedtsch. & $57 \%$ & $17 \%$ & $71 \%$ & $90 \%$ & $59^{b}$ \\
\hline Delphinium roylei Munz & $15 \%$ & $10 \%$ & $15 \%$ & $20 \%$ & $15^{\mathrm{c}}$ \\
\hline Hypericum perforatum L. & $84 \%$ & $80 \%$ & $88 \%$ & $75 \%$ & $81^{a}$ \\
\hline Podophyllum hexandrum Royle & - & - & - & $15 \%$ & $4^{c}$ \\
\hline Saussurea costus (Falc.) Lipsch. & - & - & $1 \%$ & - & $0.2^{c}$ \\
\hline
\end{tabular}

\section{Discussion}

The relative responses of the species for sprouting duration and sprouting percentage were in most cases different both between and among locations (Tables 2 and 3). Most species appeared to take longer to sprout at higher altitudes, but this was not statistically significant (Table 2). However, there was a tendency to increased sprouting at higher altitudes for all species, except for $H$. perforatum, which showed a decreased proclivity to sprout with increasing altitude (Table 3 ).

The major aim of this study was to examine the viability of cultivating medicinal plants under realistic field conditions, therefore, we expected some variation in results. It is extremely difficult to draw definitive autecological conclusions based on our field trails, but several trends were apparent. The variation in sprouting success and number of days from planting to sprouting of the medicinal plant species across locations indicated that a complex array of habitat factors such as altitude, temperature, soil, moisture and time of planting affect growth. Some delay in sprouting was generally observed in the highest sites, supporting the findings of Onwuerne (1973) that S. costus and $A$. laeve often sprouted late at high altitude due to snow and cool weather conditions. The present findings are also in agreement with those of Goel et al. (1997) who reported that when the air and soil temperatures were low at high altitudes, D. deltoidea, C. luteum and $A$. laeve sprouted in early spring. We also found that $H$. perforatum showed greatest sprouting percentage in early spring (March/April). These findings agree with those of Khan (1989) and Zaidi (1998) who reported that seed germination/sprouting of several Apiaceae and $H$. perforatum responded positively warming conditions in the early spring.

Some variation among plant heights were seen (Table 6). Delphinium roylei had the highest mean value of 37 $\mathrm{cm}$ (though as mentioned earlier, this plant subsequently had late, high mortality rates). Generally, the greatest plant heights were observed at Kandia across all species.. However, it is difficult to ascribe any meaningful trend to this data as $P$. hexandrum only grew successfully at Kalam.

Table 5. Number of days to flowering after sprouting of 6 medicinal species evaluated in four different locations under farmland conditions in Swat District, Pakistan during 2000-2001. Values with the same letter superscripts are not significantly different $(P<0.05)$.

\begin{tabular}{|c|c|c|c|c|c|}
\hline \multirow[t]{2}{*}{ Species } & \multicolumn{4}{|c|}{ Locations } & \multirow{2}{*}{$\begin{array}{c}\text { Location } \\
\text { Means } \\
\text { (days) }\end{array}$} \\
\hline & $\begin{array}{c}\text { Mingora } \\
1200 \\
\text { (m.a.s.I.) }\end{array}$ & $\begin{array}{c}\text { Dasu } \\
1400 \\
\text { (m.a.s.I.) }\end{array}$ & $\begin{array}{c}\text { Kandia } \\
1600 \\
\text { (m.a.s.I.) }\end{array}$ & $\begin{array}{c}\text { Kalam } \\
1900 \\
\text { (m.a.s.I.) }\end{array}$ & \\
\hline Aconitum laeve Royle & 18 days & - & 22 days & - & $10^{\mathrm{b}}$ \\
\hline Bunium persicum B. Fedtsch. & 35 days & 35 days & 35 days & 30 days & $34^{a}$ \\
\hline Delphinium roylei Munz & 25 days & 35 days & 25 days & 40 days & $31^{a}$ \\
\hline Hypericum perforatum L. & 10 days & 10 days & 10 days & 15 days & $11^{\mathrm{b}}$ \\
\hline Podophyllum hexandrum Royle & - & - & - & 30 days & $8^{\mathrm{b}}$ \\
\hline Saussurea costus (Falc.) Lipsch. & - & - & - & - & $-\mathrm{b}$ \\
\hline \multicolumn{6}{|c|}{ Comparison of means using Least Significant Difference test at $5 \%$ probability level $>$} \\
\hline
\end{tabular}


Table 6. Plant height $(\mathrm{cm})$ of six medicinal species evaluated in four different locations under farmland conditions in Swat District, Pakistan during 2000-2001. Values with the same letter superscripts are not significantly different $(\mathrm{P}<0.05)$.

\begin{tabular}{|c|c|c|c|c|c|}
\hline \multirow[t]{2}{*}{ Species } & \multicolumn{4}{|c|}{ Locations } & \multirow{2}{*}{$\begin{array}{l}\text { Location } \\
\text { Means } \\
\text { (cm) }\end{array}$} \\
\hline & $\begin{array}{c}\text { Mingora } \\
1200 \\
\text { (m.a.s.I.) }\end{array}$ & $\begin{array}{c}\text { Dasu } \\
1400 \\
\text { (m.a.s.l.) }\end{array}$ & $\begin{array}{c}\text { Kandia } \\
1600 \\
\text { (m.a.s.l.) }\end{array}$ & $\begin{array}{c}\text { Kalam } \\
1900 \\
\text { (m.a.s.l.) }\end{array}$ & \\
\hline Aconitum laeve Royle & $15 \mathrm{~cm}$ & - & $20 \mathrm{~cm}$ & - & $8.7^{\mathrm{b}}$ \\
\hline Bunium persicum B. Fedtsch. & $13 \mathrm{~cm}$ & $13 \mathrm{~cm}$ & $19 \mathrm{~cm}$ & $15 \mathrm{~cm}$ & $15^{\mathrm{ab}}$ \\
\hline Delphinium roylei Munz & $35 \mathrm{~cm}$ & $40 \mathrm{~cm}$ & $40 \mathrm{~cm}$ & $35 \mathrm{~cm}$ & $37^{a}$ \\
\hline Hypericum perforatum $\mathrm{L}$. & $11 \mathrm{~cm}$ & $15 \mathrm{~cm}$ & $18 \mathrm{~cm}$ & $14 \mathrm{~cm}$ & $15^{\mathrm{ab}}$ \\
\hline Podophyllum hexandrum Royle & - & - & - & 70 & $18^{\mathrm{ab}}$ \\
\hline Saussurea costus (Falc.) Lipsch. & - & - & - & - & $0^{\mathrm{b}}$ \\
\hline
\end{tabular}

Bunium persicum took the minimum number of days to achieve $50 \%$ sprouting (mean of 31 days). This was significantly less than the other species in the test (Table 2).

The greatest degree of sprouting was observed for $D$. roylei, followed by $H$. perforatum. These were significantly higher than all other species. Saussurea costus, P. hexandrum and $A$. laeve showed very poor sprouting (Table 3 ).

Soil chemistry and texture are also likely to be very important. Not surprisingly, Khan (1995) reported that the height of alpine medicinal plants was greatly affected by the fertility and moisture contents of the soil. Certainly, in our study most species (with the notable exception of $P$. hexandrum, which only grew at one site) attained greatest heights in the sandier soil at Kandia. Bunium persicum, for example, grew tallest and sprouted most successfully at Kandia, supporting the contention of Khan (1998) that sandy soil and dry climate is more suitable for Bunium cultivation. Overall, however, we observed very low sprouting percentage and survival of $S$. costus, $A$. laeve and $P$. hexandrum in the farmland conditions. This starkly contrasts with Verlet and Leclereq (1997) who reported that farmland habitats are favorable for some medicinal plants like Valeriana officinale L. and Rauvolfia serpentina (L.) Benth. ex Kurz. In the present study though, the farm lands were not fertile and soils were poorly developed, primarily due to mountain topography where the upper soil layers had eroded to stones and gravels. Even with some manuring these sites were not conducive for good growth of these medicinal species.

Significant differences among species for survival after sprouting were observed (Table 4). Hypericum perforatum exhibited the highest survival followed by $B$. persicum with these being significantly greater than all other species. Survival rates were assessed 10 months after planting, by which time clear trends were apparent, however, it is worth noting that after showing quite good initial growth, many $D$. roylei plants started to wilt and died 10 to 11 month after planting. Survival percentages of $S$. costus, $A$. laeve and $P$. hexandrum were very poor under farmland conditions.

The poor survival referred to above could be due to shallow nature of the soil and/or the absence of associated

Table 7. Productive yield of usable plant parts in $\mathrm{kg} / \mathrm{ha}$ of six medicinal species evaluated in four different locations under farmland conditions in Swat District, Pakistan during 2000-2001.

\begin{tabular}{|c|c|c|c|c|c|c|}
\hline \multirow[t]{2}{*}{ Species } & \multirow{2}{*}{$\begin{array}{l}\text { Plant } \\
\text { Organ }\end{array}$} & \multicolumn{4}{|c|}{ Locations } & \multirow{2}{*}{$\begin{array}{c}\text { Location } \\
\text { Means } \\
\text { (kg/ha) }\end{array}$} \\
\hline & & $\begin{array}{c}\text { Mingora } \\
1200 \\
\text { (m.a.s.I.) }\end{array}$ & $\begin{array}{c}\text { Dasu } \\
1400 \\
\text { (m.a.s.l.) }\end{array}$ & $\begin{array}{c}\text { Kandia } \\
1600 \\
\text { (m.a.s.I.) }\end{array}$ & $\begin{array}{c}\text { Kalam } \\
1900 \\
\text { (m.a.s.I.) }\end{array}$ & \\
\hline Aconitum laeve Royle & Rhizome & $96 \mathrm{~kg} / \mathrm{ha}$ & - & $49 \mathrm{~kg} / \mathrm{ha}$ & - & 73 \\
\hline Bunium persicum B. Fedtsch. & Flower & $21 \mathrm{~kg} / \mathrm{ha}$ & $16 \mathrm{~kg} / \mathrm{ha}$ & $24 \mathrm{~kg} / \mathrm{ha}$ & $5 \mathrm{~kg} / \mathrm{ha}$ & 17 \\
\hline Delphinium roylei Munz & Rhizome & $853 \mathrm{~kg} / \mathrm{ha}$ & $1066 \mathrm{~kg} / \mathrm{ha}$ & $709 \mathrm{~kg} / \mathrm{ha}$ & $1386 \mathrm{~kg} / \mathrm{ha}$ & 1004 \\
\hline \multirow[t]{2}{*}{ Hypericum perforatum $\mathrm{L}$. } & Flower & $373 \mathrm{~kg} / \mathrm{ha}$ & $320 \mathrm{~kg} / \mathrm{ha}$ & $533 \mathrm{~kg} / \mathrm{ha}$ & $426 \mathrm{~kg} / \mathrm{ha}$ & 413 \\
\hline & Shoot/Leaf & $1066 \mathrm{~kg} / \mathrm{ha}$ & $746 \mathrm{~kg} / \mathrm{ha}$ & $1280 \mathrm{~kg} / \mathrm{ha}$ & $960 \mathrm{~kg} / \mathrm{ha}$ & 1013 \\
\hline Podophyllum hexandrum Royle & Rhizome & - & - & - & $90 \mathrm{~kg} / \mathrm{ha}$ & 23 \\
\hline Saussurea costus (Falc.) Lipsch. & Rhizome & - & - & - & - & - \\
\hline
\end{tabular}




\section{Sher et al. - Ex-situ Management Study of Some High Value Medicinal Plant Species in Swat, Pakistan}

Table 8. Economic analysis of yield data of medicinal plants, cereal crops and a cash crop of the experiment conducted in four different locations under farmland conditions in Swat, Pakistan during the year 2000-2001. a. Hypericum perforatum $\mathrm{L}$. flower yield and sale rate. b. Hypericum perforatum $\mathrm{L}$. shoot/leaf yield and sale rate.

\begin{tabular}{|l|c|c|c|c|l|}
\hline Species & $\begin{array}{c}\text { Yield } \\
\text { (kg/ha.) }\end{array}$ & $\begin{array}{c}\text { Sale Rate } \\
\text { (Rs/kg) }\end{array}$ & $\begin{array}{c}\text { Income/ha. } \\
\text { (Rs/ha.) }\end{array}$ & $\begin{array}{c}\text { Cost/ha. } \\
\text { (Rs/ha.) }\end{array}$ & $\begin{array}{c}\text { Net Income } \\
\text { (Rs/ha.) }\end{array}$ \\
\hline Medicinal Plants \\
\hline Aconitum laeve Royle & 90 & 30 & 2700 & 31680 & -28980 \\
\hline Bunium persicum B. Fedtsch. & 24 & 3000 & 27000 & 53070 & 18930 \\
\hline Delphinium roylei Munz & 1386 & 20 & 27780 & 31680 & -3970 \\
\hline Hypericum perforatum L. & $533^{\mathrm{a}} / 1280^{\mathrm{b}}$ & $100^{\mathrm{a}} / 4.8^{\mathrm{b}}$ & 59490 & 31680 & 27810 \\
\hline Podophyllum hexandrum Royle & 90 & 20 & 1800 & 31680 & -29880 \\
\hline Saussurea costus (Falc.) Lipsch. & 0 & 30 & 0 & 31680 & -31680 \\
\hline Cereal Crops & \multicolumn{5}{|l|}{} \\
\hline Triticum aestivum L. & 4800 & 10 & 48000 & 33000 & 15000 \\
\hline Zea mays L. & 5760 & 8 & 4680 & 32640 & 13440 \\
\hline Cash Crops & 2162 & 30 & 64872 & 34000 & 30872 \\
\hline
\end{tabular}

species that are commonly present in-situ; these may help by providing shelter or perhaps creating richer, more humic soils. Joshi and Rawat (1999) observed that alpine medicinal plants such as $C$. luteum, S. costus and $P$. hexandrum prefer to grow in the forest habitat with the humus rich soils and with high moisture content. Similarly, Khan (1989) reported that perennial medicinal plant species like Lavetaria, Dioscorea, Saussurea and Podophyllum grow best in humus rich soil with high $\mathrm{pH}$ values.

Significant differences among species for days to flowering after sprouting (Table 5) were observed. Bunium persicum and $D$. roylei took significantly longer to flower than other species. In species where survival rates allowed comparison, there was some evidence that altitude retarded flowering, e.g., for $D$. roylei and Viola serpens Wall. ex Ging.

In the present study the medicinal plants generally flowered earlier at the lower elevation sites. Lower temperatures in higher elevations could be the plausible explanation for this delayed flowering. This phenomenon is well documented; Thakur and Bhatt (1980) reported that plants remain dormant and exhibit delayed flowering primarily due to low temperatures in higher elevations, and similarly, Singh et al. (1998) found that alpine medicinal plants remain dormant in early spring, delaying flowering until May and June. The same effect was observed by Zaidi (1998) who reported that low temperature treatment delays flowering in $A$. rosea.

Due to poor sprouting and/or no survival, no rhizome yield for S. costus at any of four sites was obtained. Similarly $P$. hexandrum failed to give any rhizome yield at three of four sites. While $A$. laeve was found to have no rhizome yield at two locations. Rhizome yield of $A$. laeve showed a decrease at the higher elevation site $(96 \mathrm{~kg} / \mathrm{ha}$ at Mingora vs. $49 \mathrm{~kg} / \mathrm{ha}$ at Kandia), while $D$. roylei generally exhibited a rise in rhizome yield with increasing elevation. This latter species, grew quite well and developed rhizomes, yet failed to set seeds or develop fruit (and many plants subsequently died). The yield in both shoot/leaf and flowers of $H$. perforatum was certainly not reduced, but rather, generally seemed to be enhanced with increasing altitude, while no discernible trend of increased flower yield was evident for B. persicum.

Economic analyses of yield data (Table 8) revealed that $H$. perforatum and $B$. persicum have reasonable economic potential for supplementing the farmers' income. Economically, these two species appeared comparable with cereal crops in this area, although as a cash crop, tobacco clearly remains a more attractive proposition for farmers, given its relatively high price. Although, it seems unlikely that medicinal plants can replace any of the established crops in upper Swat at the moment, it is possible that the short growing period of these medicinal plant species coupled with their potentially high market value in relation to cereal or cash crops could be an added advantage in their commercial production. For example, Zaidi (1998) reported that cultivation of Althaea officinalis $L$ has good potential for supplementing the farmers' income. Similar results were also reported by Khan (1998) who stated that Valerian root cultivation might earn foreign exchange and supplement the cash income of farmers. Likewise, Fuller (1991) described methods of cultivation of Colchicum autumnale $\mathrm{L}$. to supplement cash income of the farmers in the U.S.A. 


\section{Conclusion}

Our study shows that it is possible to cultivate some of these medicinal plants ex-situ in marginal conditions. However, the productive yield of $D$. roylei, $H$. perforatum and $B$. persicum were not very encouraging. Worse still, $S$. costus, $P$. hexandrum and $A$. laeve, more or less failed to survive. Whatever, the specific causes, the results suggest that cultivating these species in Swat is likely to be marginal at best. But we acknowledge that this is a preliminary assessment and any plant cultivation is obviously site specific, thus it is difficult to make blanket statements. Moreover, the low survival of some species made species comparisons difficult. Nevertheless, our study used the type of marginal farmlands, typical conditions and resources available to rural communities in upper Swat, therefore, it would seem that unless better incentives are offered, these medicinal plants are unlikely to provide attractive alternatives to farmers at this time. Although economically comparable to cereal crops, medicinal plants seem unlikely to be able to replace these to any great extent, given the fact that farmers are familiar with cereals and may be dependent upon them for self-consumption. Similarly, tobacco is still regarded as the best cash crop in most of these communities. With increasing scarcity and increasing prices, it is possible that $H$. perforatum and $B$. persicum may become commercially viable in the future. For the present, however, it seems that propagation of these medicinal plants at the margins of the farmlands and their in-situ protection, management and conservation of their natural habitat could be more fruitful.

\section{Literature Cited}

Fuller, D.O. 1991. Medicines from the Wild: An overview of the U.S. native medicinal trade and its conservation implications. TRAFFIC, Washington D.C.

Goel, A.K., S.G. Sharma \& A.S. Rajendran. 1997. Ex-situ conservation of Encephalartos Lehm. (Zamiaceae) in Botanic garden, National Botanical Research Institute, Lucknow (India). Indian Journal of Forestry 20:263-264.

Hussain, F. \& H. Sher. 1998. Income generation from the trade and cultivation of wild medicinal plants, District Swat. Pp. 41-48 in Proceedings of Wild Plant Resources of Northern Pakistan, Workshop. Pakistan Forest Institute, Peshawar, Northwest Frontier Province, Pakistan. May 11-12, 1998.
Joshi, D.I.V. \& C.S. Rawat. 1999. Need for conservation and propagation of alpine medicinal plants. Indian Journal of Forestry 23:811-814.

Khan, A.A. 1989. Propagation and regeneration technology of pharmacopoeial medicinal plants of temperate regions of Pakistan. Pakistan Forestry Institute, Peshawar, Northwest Frontier Province, Pakistan. Bulletin No. 3.

Khan, A.A. 1991. Marketing of herbal drugs and its problems. Pp. 69-72 in Proceedings of the National Workshop on Appropriate Use of Medicinal Plants in Traditional Medicine. National Institute of Health, Islamabad, Pakistan. November 20-21, 1991.

Khan, M.H. 1998. Biodiversity of medicinal and economic plants in Northern Himalayan region, Azad Kashmir. Pp. 6-10 in Proceedings of Wild Plant Resources of Northern Pakistan, Workshop. Pakistan Forest Institute, Peshawar, Northwest Frontier Province, Pakistan. May 11-12, 1998.

Lange, D. 1998. Europe's Medicinal and Aromatic Plants: Their use, trade and conservation. TRAFFIC, Cambridge, U.K.

Onwueme, I.C. 1973. Sprouting process in yam. (Dioscorea spp.) tuber pieces. Journal of Agricultural Science 88:375-379.

Singh, V.K., Z.A. Ali \& M.K. Siddiqui. 1998. Folk Medicinal plants of the Gorhwal and Kuman forest of Uttar Pradesh, India. Hamdard Medicus 40:35-47.

Steel, R.G.D. \& J.H. Torrie. 1980. Principles and Procedures of Statistics: A biometrical approach. 2nd edition. McGraw-Hill Book Company, New York.

Thakur, R.N. \& B.K. Bhatt. 1980. Phytophthera root rot of Atropa belladonna in Kashmir valley. Indian Jouranal of Mycology and Plant pathology 9:82-89.

Verlet, N. \& G. Leclercq. 1997. Towards a model of technical and economic optimization of specialist minor crops converted action AIR3-CT-94-2076. 1995-96. Commission Européenne Direction générale de l'Agriculture (D.G VI) Unité F. II.3.

Zaidi, S.H. 1998. Cultivation of condiments and spices in Punjab and NWFP, Pakistan. Pakistan Forest Institute. Peshawar, Northwest Frontier Province, Pakistan. Bulletin 3:14-24. 